Diabetologia 11, 151-158 (1975)

(c) by Springer-Verlag 1975

\title{
Serum IRI in Insulin-Treated Diabetics during a 24-Hour Period
}

\author{
S. Munkgaard Rasmussen*, L. G. Heding, E. Parbst, Aa. Vølund \\ Hvidøre Hospital and Novo Research Institute, Denmark \\ Received: August 16, 1974, and in revised form: January 8, 1975
}

\begin{abstract}
Summary. Serum immunoreactive insulin extracted with acid ethanol (total IRI) and blood glucose were measured in two groups of diabetics and a control group during 24-hour periods. One group of diabetics had received insulin for less than 1 month, and none had yet developed insulin antibodies. The other had been treated with insulin for 2 years or more. The average level of total IRI in the diabetics without antibodies was similar to that in the normals, but highly elevated in diabetics with antibodies, although the blood glucose levels were similar in the two diabetic groups. The increase in total IRI after the insulin injections was more rapid in patients receiving quick-acting insulin and most pronounced in those with the highest levels of total IRI. The total IRI peaked in
\end{abstract}

the afternoon and dropped during the night. The short-term insulin-treated patients showed a better degree of diabetes control than those treated for 2 years or more. No correlation was found however, between the total IRI level and the degree of control in the latter group. The patients with the highest levels of total IRI had the highest frequency of hypoglycemic episodes. This is in agreement with the concept that the insulin antibodies may function as a circulating depot, which releases insulin irrespective of the metabolic need.

Key-words: Immunoreactive insulin, insulin antibodies, diabetes control, insulin treatment, $24 \mathrm{hr}$ variation, juvenile diabetes, hypoglycemia.
Several investigations concerning concentrations of immunoreactive insulin (IRI) in normal subjects during a period of $24 \mathrm{hrs}$ or more have been reported $[10,18]$ or included in studies of diabetics. The $24 \mathrm{hr}$ variation in IRI has also been studied in non-insulin treated diabetics $[9,14,29]$. The variation in IRI after subcutaneous injection of clinical doses of insulin has been studied in diabetics without insulin antibodies $[1,12,13,21,22,28]$. Using an acid ethanol extraction method for the determination of total IRI in sera containing endogenous insulin antibodies, it has been demonstrated that the daily insulin injections caused variations in the total IRI concentration [16].

The purpose of the present investigation was to study the $24 \mathrm{hr}$ variation of total IRI in a group of diabetics treated with insulin for less than 1 month, i.e., before development of insulin antibodies, and in another group of diabetics treated with insulin for 2 years or more. Furthermore, an attempt was made to see whether the level of total IRI was correlated with the degree of diabetic control.

\section{Material and Methods}

Five hospitalized diabetic patients were studied within the first month of insulin treatment. Two cases were treated with insulin from the onset of diabetes. The other three were treated for a time with diet and/

* Present adress: Frederiksberg Hospital, Medicinsk afdeling B, DK-2000 Copenhagen F., Denmark or oral antidiabetic agents, but were transferred to insulin because of unsatisfactory control (hyperglycemia, glucosuria, acetonuria, and weight loss). These patients are referred to as the short-term group.

Another group of 19 patients treated with insulin for 2 years or more was studied during hospitalization for check-up or improvement of their diabetic control. All these patients suffered from diabetes of juvenile type (ketosis-prone and insulin-requiring), but none had ketoacidosis at the time of the study. These patients are referred to as the long-term group. Table 1 gives further data on the patients and details of the regimen.

For comparison, four normal volunteers of normal weight (male students) were hospitalized at the same time and studied under the same conditions of diet and exercise as the diabetics.

The diet was planned by a dietician to suit the individual weight and degree of activity. Table 1 gives the total calorie intake per $24 \mathrm{hrs}$ and the weight index (i.e. body weight divided by the ideal body weight according to life insurance tables). Exercise consisted of normal every-day activities.

Blood samples were drawn at 08.00 , immediately before the insulin injection and breakfast, at 09.00, and 11.30 before lunch, at 15.00 the afternoon following snack, at 18.00 just after supper (and $30 \mathrm{~min}$ after the insulin injection, if this was given twice daily), at 21.00 following the evening snack, at 02.00 , and again at 08.00. Extra blood samples were obtained from the normal subjects at about the time of the three main 
meals. In three of the patients (F. P., E. Ca., and H. R. $\mathrm{K}$.), the blood sampling schedule began at 11.30 and ended at 09.00 the following morning. However, the results are drawn up as if the patients had been followed from 08.00 in the morning until 02.00 the following night, as this does not influence the interpretation. In a few other patients, the second 08.00 sample is also missing. total IRI concentration was determined after acid ethanol extraction of the serum [16]. The guinea-pig antibody used in the immunoassay gave identical standard curves with porcine, bovine, and human insulin. In serum devoid of insulin antibodies, the total IRI concentration was equal to the IRI concentration measured by direct insulin immunoassay (own observations). At IRI levels below $50 \mu \mathrm{U} / \mathrm{ml}$, the stand-

Table 1. Clinical characteristics of the diabetic patients

\begin{tabular}{|c|c|c|c|c|c|c|c|c|c|}
\hline Initials & Sex & $\begin{array}{l}\text { Age } \\
\text { (years) }\end{array}$ & $\begin{array}{l}\text { Duration of in- } \\
\text { sulin treatment }\end{array}$ & $\begin{array}{l}\text { Morning insulin } \\
\text { dose (I.U.) }\end{array}$ & $\begin{array}{l}\text { Evening insulin } \\
\text { dose (I.U.) }\end{array}$ & $\begin{array}{l}\text { Diet } \\
\text { (kcal) }\end{array}$ & $\begin{array}{l}\text { Body weight } \\
(\mathrm{kg})\end{array}$ & $\begin{array}{l}\text { Weight } \\
\text { index }\end{array}$ & $\begin{array}{l}\text { Shown } \\
\text { in Fig. }\end{array}$ \\
\hline S.H. & M & 27 & $<1$ month & $12 \mathrm{~L}$ & 0 & 1540 & 84.3 & 1.11 & 2 \\
\hline J.D. & M & 32 & $<1$ month & $28 \mathrm{~L}$ & 0 & 1700 & 64.3 & 0.99 & 2 \\
\hline Å.L. & $\mathrm{F}$ & 36 & $<1$ month & $24 \mathrm{~L}$ & 0 & 1900 & 44.7 & 0.79 & 2 \\
\hline L.S. & $\mathbf{M}$ & 38 & $<1$ month & $20 \mathrm{~L}$ & 0 & 2100 & 94.1 & 1.11 & 2 \\
\hline M. O.O. & M & 54 & $<1$ month & $28 \mathrm{R}$ & 0 & 1900 & 59.8 & 0.82 & 2 \\
\hline E.C. & M & 34 & 12 years & $40 \mathrm{~L}$ & 0 & 2600 & 72.4 & 0.93 & 3 \\
\hline H. R.K. & M & 66 & 19 years & $30 \mathrm{~L}$ & 0 & 2240 & 70.4 & 1.03 & 3 \\
\hline J. V.M. & $\mathbf{M}$ & 46 & 23 years & $10 \mathrm{~L}$ & 0 & 2400 & 64.4 & 0.96 & 3 \\
\hline J.S. & $\mathbf{M}$ & 60 & 29 years & $20 \mathrm{NPH}$ & 0 & 2100 & 61.5 & 0.90 & 3. \\
\hline E. Cl. ${ }^{1}$ & $\mathrm{~F}$ & 63 & 6 years & $20 \mathrm{R}$ & 0 & 1900 & 45.1 & 0.96 & 3 \\
\hline H.L. & $\mathbf{M}$ & 43 & 20 years & $+8 \mathrm{SL}$ & 0 & 2450 & 78.0 & 1.02 & 3 \\
\hline S. E. N. & M & 17 & 11 years & $24 \mathrm{~L}+8 \mathrm{SL}$ & $12 \mathrm{~L}$ & 2400 & 65.1 & 0.98 & 4 \\
\hline H. H. L. & M & 68 & 28 years & $12 \mathrm{NPH}+8 \mathrm{SL}$ & $8 \mathrm{NPH} \quad$ [later) & 2240 & 59.8 & 0.95 & 4 \\
\hline A.. N. B. & M & 71 & 10 years & $16 \mathrm{~A}$ & $6 \mathrm{~L}\left(+4 \mathrm{~A} 1 \frac{1}{2} \mathrm{~h}\right.$ & 2400 & 59.0 & 0.79 & 4 \\
\hline S. K. H. & M & 50 & 11 years & $+8 \mathrm{SL}$ & $8 \mathrm{~L}$ & 2400 & 68.5 & 1.04 & 4 \\
\hline F.P. & M & 37 & 6 years & $20 \mathrm{~L}$ & $12 \mathrm{~L}$ & 2450 & 68.7 & 1.00 & 4 \\
\hline E. Ca. & M & 55 & 17 years & $24 \mathrm{~L}+8 \mathrm{OI}$ & $16 \mathrm{~L}$ & 2100 & 66.1 & 0.94 & 4 \\
\hline A. $\mathrm{K}$. & $\mathrm{F}$ & 53 & 28 years & $10 \mathrm{NPH}$ & $8 \mathrm{NPH}$ & 1700 & 50.7 & 0.92 & 4 \\
\hline O. B.L. & $\mathbf{M}$ & 17 & 11 years & $28 \mathrm{~L}+8 \mathrm{~A}$ & $8 \mathrm{~L}$ & 2500 & 58.0 & 0.94 & 5 \\
\hline E.S.N. & M & 23 & 2 years & $24 \mathrm{NPH}$ & $8 \mathrm{NPH}$ & 2550 & 79.0 & 1.12 & 5 \\
\hline P. L. & $\mathbf{M}$ & 33 & 4 years & $20 \mathrm{R}+8 \mathrm{~A}$ & $8 \mathrm{R}$ & 2450 & 68.3 & 0.99 & 5 \\
\hline L.E. & $\mathbf{M}$ & 18 & 11 years & $+8 \mathrm{~A}$ & $8 \mathrm{~L}$ & 2400 & 63.4 & 0.91 & 5 \\
\hline E. Cl. ${ }^{2}$ & F & 63 & 6 years & $16 \mathrm{R}$ & $6 \mathrm{R}$ & 1900 & 45.1 & 0.96 & 5 \\
\hline E. O. & M & 31 & 11 years & $+12 \mathrm{~A}$ & $6 \mathrm{~L}$ & 2000 & 67.2 & 0.99 & 4 \\
\hline K. F. & $\mathrm{M}$ & 25 & 3 years & $+16 \mathrm{SL}$ & $6 \mathrm{~L}$ & 2400 & 83.0 & 1.13 & 5 \\
\hline
\end{tabular}

The abreviations appearing after the insulin doses stand for the following insulin preparations: $\mathrm{L}=\mathrm{Lente}, \mathrm{R}=\mathrm{Rapitard}$, $\mathrm{NPH}=$ Retard, $\mathrm{SL}=$ Semilente, $\mathrm{OI}=$ ordinary insulin, $\mathrm{A}=$ Actrapid.

E. Cl. ${ }^{1}$ and E. Cl. ${ }^{2}$ represent the same patient studied while treated with a single morning injection and when switched to treatment with two daily insulin injections 5 days later.

The blood samples were drawn from fresh venous punctures or through an indwelling catheter in an anticubital vein for a maximum of $8 \mathrm{hrs}$. The blood was allowed to clot at room temperature before centrigugation. The serum was stored at $-20^{\circ} \mathrm{C}$ until the time of insulin assay.

The blood glucose concentration (BG) was determined in capillary blood samples by a glucose oxidase method (C. F. Boehringer \& Söhne, Mannheim). The insulin binding to IgG was measured by immunoelectrophoresis [8]. The lower limit of significant insulin binding to IgG is about $0.04 \mathrm{mU} / \mathrm{ml}$. The concentration of immunoreactive insulin (IRI) in normal sera was determined by insulin immunoassay, and the ard deviation (SD) between assays was about $4 \mu \mathrm{U} /$ $\mathrm{ml}$, whereas the SD within assays was about $2 \mu \mathrm{U} / \mathrm{ml}$. At higher IRI levels, the SD's between and within assays were about $5 \%$ and $3 \%$, respectively [16]. The samples obtained during the $24 \mathrm{hr}$ study of a given patient were measured in the same assay.

The M-value, an index of the quality of blood glucose control [30], was calculated, using a modified table to account for the difference between blood sugar as determined by the Hagedorn-Jensen method and by the glucose oxidase method [25]. The mean urine glucose excretion (polarimetric determination), acetonuria and hypoglycemia were also evaluated for the M-value period of about 6 days. This period in- 
cluded in all the cases the 24 hr period during which blood samples were drawn for the IRI determinations. The patients were classified as positive with respect to acetonuria if one or more distinctly positive reactions according to Legal's test were obtained during the period of observation. The corresponding criterion for hypoglycemia was one or more episodes with clinical symptoms of hypoglycemia in conjunction with a blood glucose concentration less than $55 \mathrm{mg} / 100 \mathrm{ml}$.

\section{Results}

Fig. 1 shows the $24 \mathrm{hr}$ variation of IRI and BG in the four normal subjects. After the morning meal, two of the subjects showed increases in IRI amounting to 18 and $25 \mu \mathrm{U} / \mathrm{ml}$, whereas the other two showed no significant change. Both after lunch and supper, all of results (J.V.M. ${ }^{1}$ and J.V.M. ${ }^{2}$ ) are shown in the figure and appear to be quite similar.

Fig. 4 and 5 present the variations in total IRI and $B G$ in the long-term patients treated with two daily injections. All these patients showed increases in total IRI from 08.00 to 11.30 . In some cases a second rise in IRI could be observed after the evening injection. In one case (E. Ca.) total IRI showed an inexplicable drop from 0800 to 0900 .

One of the patients in Fig. 5 (E. Cl. ${ }^{2}$ ) is also represented in Fig. 3 (E. Cl. ${ }^{1}$ ) as this patient was studied at first when treated with a single dose and then after a switch to two daily insulin doses 5 days later, see Table 1.

The mean $24 \mathrm{hr}$ level of total IRI shown in Table 2 was calculated as the area under the IRI curve (Fig. 2-5) divided by the length of the time interval. As the method was not available in the beginning of

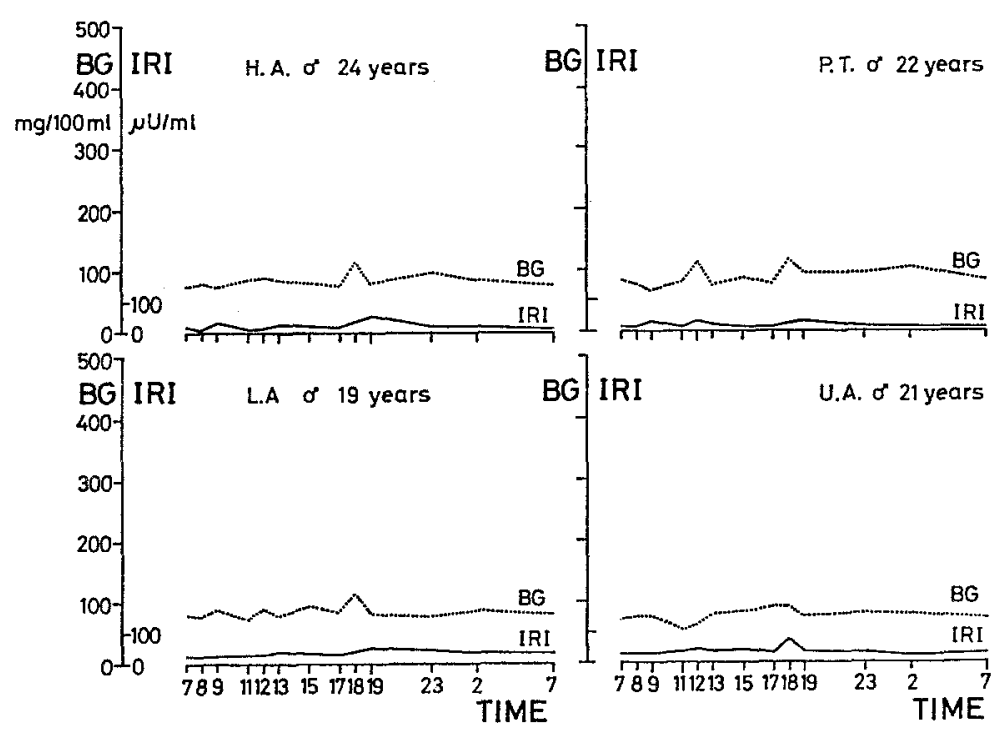

Fig. 1. Twenty-four hour variations in IRI and BG in 4 normal subjects

four showed increases in IRI ranging from 10 to 44 $\mu \mathrm{U} / \mathrm{ml}$.

Fig. 2 shows the results from the five short-term diabetics treated with insulin for less than one month. Four of the patients showed a rise in IRI after the morning injection, whereas in the 5th case IRI remained below $12 \mu \mathrm{U} / \mathrm{ml}$ throughout the $24 \mathrm{hrs}$. The increases in IRI ranged from 12 to $53 \mu \mathrm{U} / \mathrm{ml}$ in these patients.

Fig. 3 shows the variation in total IRI and BG in the six patients who were treated with a single daily insulin injection in the morning and had been on insulin for two years or more. All these long-term patients showed an increase in total IRI after the injection. In one of the patients, the $24 \mathrm{hr}$ variation was studied twice at an interval of $2 \frac{1 / 2}{2}$ months. Both sets the study, the insulin binding to IgG was determined only in 14 out of 24 cases. There was no variation in this parameter between the different sampling times.

A comparison of the long-term diabetics on a single daily insulin injection with those on two injections daily revealed no statistically significant differences (5\% level, Wilcoxon's test) between any of the parameters. Hence, subsequently, all the long-term insulin treated patients will be pooled into a single group. The mean increase in total IRI during the interval from 08.00 to 11.30 was $230 \mu \mathrm{U} / \mathrm{ml}$ (range 71 to 565 $\mu \mathrm{U} / \mathrm{ml}$ ) in the 7 patients of the long-term group who received Actrapid or ordinary insulin in the morning. The corresponding mean increase in the 7 patients who were treated with Lente, Rapitard or NPH-insulin was $36 \mu \mathrm{U} / \mathrm{ml}$ (range 18 to $61 \mu \mathrm{U} / \mathrm{ml}$ ). This difference is 
statistically significant according to Wilcoxon's test $(P<0.01)$.

Fig. 6 shows the means of total IRI and BG of the short- and long-term patients. It appears that the mean $24 \mathrm{hr}$ variation in total IRI consists of an increase after the morning injection, culminating in a maximal level in the afternoon or evening, followed by a drop during ficant correlation (5\% level, Spearman's rank correlation coefficient) in the long-term group between the mean total IRI on the one hand and the M-value or urine glucose excretion on the other. The mean total IRI levels were similar in the long-term patients with and without episodes of acetonuria, whereas there was a statistically significant difference $(P<0.05$, Wil-

Table 2. Total IRI and control of diabetes

\begin{tabular}{|c|c|c|c|c|c|}
\hline Initials & $\begin{array}{l}\text { Duration of in- } \\
\text { sulin treatment }\end{array}$ & $\begin{array}{l}\text { Mean 24-hour } \\
\text { total IRI }(\mu \mathrm{U} / \mathrm{ml})\end{array}$ & $\begin{array}{l}\text { Insulin binding } \\
\text { to } \operatorname{IgG}(\mathrm{mU} / \mathrm{ml})\end{array}$ & M-value & $\begin{array}{l}\text { Mean urine } \\
\text { glucose ex- } \\
\text { cretion }(\mathrm{g} / 24 \mathrm{~h})\end{array}$ \\
\hline S.H. & $<1$ month & 27 & 0.01 & 12 & 5 \\
\hline J. D. & $<1$ month & 7 & 0.01 & 25 & 60 \\
\hline À. L. & $<1$ month & 13 & 0.01 & 12 & 1 \\
\hline L.S. & $<1$ month & 17 & 0.01 & 22 & 2 \\
\hline M.O.O. & $<1$ month & 24 & 0.00 & 8 & 12 \\
\hline E. C. & 12 years & 483 & 一 & 46 & 155 \\
\hline H. R. K. & 19 years & 191 & - & 72 & 159 \\
\hline J V.M. & 23 years & 76 & - & 51 & 47 \\
\hline J.S. & 29 years & 207 & 0.71 & 28 & 50 \\
\hline E.Cl. & 6 years & 94 & 0.53 & 29 & 22 \\
\hline H. L. & 20 years & 129 & 2.15 & 37 & 28 \\
\hline S.E.N. & 11 years & 205 & - & 37 & 0 \\
\hline H. H. L. & 28 years & 523 & - & $60^{\circ}$ & 12 \\
\hline Å.N.B. & 10 years & 290 & - & 34 & 60 \\
\hline S. K. H. & 11 years & 288 & - & 41 & 20 \\
\hline F.P. & 6 years & 82 & - & 19 & 13 \\
\hline E. Ca. & 17 years & 365 & - & 20 & 4 \\
\hline A. K. & 28 years & 378 & - & 38 & 0 \\
\hline O. B. L. & 11 years & 2047 & 4.57 & 27 & 97 \\
\hline E.S.N. & 2 years & 958 & 2.20 & 39 & 92 \\
\hline P.L. & 4 years & 1672 & 1.47 & 31 & 47 \\
\hline L.E. & 11 years & 1282 & 1.36 & 21 & 27 \\
\hline E. O. & 11 years & 511 & 4.15 & 21 & 48 \\
\hline K.F. & 3 years & 116 & 1.00 & 16 & 45 \\
\hline \multicolumn{2}{|c|}{$\begin{array}{l}\text { Mean } \pm \text { SD of short-term } \\
\text { patients ( }<1 \text { month) }\end{array}$} & $18 \pm 8$ & $0.008 \pm 0.004$ & $16 \pm 7$ & $16 \pm 25$ \\
\hline \multicolumn{2}{|c|}{$\begin{array}{l}\text { Mean } \pm S D \text { of long-term } \\
\text { patients }(\geq 2 \text { years) }\end{array}$} & $521 \pm 567$ & $2.02 \pm 1.45$ & $35 \pm 15$ & $39 \pm 47$ \\
\hline \multicolumn{2}{|c|}{$\begin{array}{l}\text { Statistical significance } \\
\text { (Wilcoxon's test) }\end{array}$} & $P<0.001$ & $P<0.001$ & $P<0.005$ & $0.05<P<0.1$ \\
\hline
\end{tabular}

Acetonuria : + means a distinct positive reaction according to Legal's test, otherwise 0 .

Hypoglycemia: + means clinical signs of hypoglycemia in conjunction with a blood glucose test showing less than $55 \mathrm{mg} / 100$ $\mathrm{ml}$, otherwise 0 .

the night. The mean $\mathrm{BG}$ is highest in the long-term group, the difference being statistically significant at the BG curve peak at $09.00(P<0.01$, Wilcoxon's test). The two IRI curves are obviously different at all times.

From Table 2 it appears that the M-value is significantly lower in the short-term than in the long-term insulin treated patients. The urine glucose excretion shows a similar, though not statistically significant, difference. However, there was no statistically signi- coxon's test) between total IRI in the group of twelve patients with episodes of hypoglycemia (mean: 683 $\mu \mathrm{U} / \mathrm{ml}, \mathrm{SD}: 654 \mu \mathrm{U} / \mathrm{ml}$ ) and the seven without (mean: $243 \mu \mathrm{U} / \mathrm{ml}, \mathrm{SD}: 193 \mu \mathrm{U} / \mathrm{ml})$.

\section{Discussion}

A direct immunoassay for the determination of IRI in patients with circulating insulin antibodies will give 
either too high or too low results. A double-antibody immunoassay [24] was used to study insulin patterns in insulin-treated diabetics [23]. Such an assay will give erroneously high results, as a portion of the labelled insulin will be bound to endogenous antibodies, thus reducing the amount available for binding to the first antibody. Since the second antibody does not precipitate antibodies to endogenous insulin, the precipitate will contain less labelled insulin than the amount obtained with the corresponding standard. In [24] it was also shown that the recovery of added human insulin was over $100 \%$ (up to $200 \%$ ) in 8 out of 9 samples a positive correlation to the insulin binding to $\mathrm{IgG}$ (median about $1 \mathrm{mU} / \mathrm{ml}$, range 0.01 to $12 \mathrm{mU} / \mathrm{ml}$ ) [31]. In accordance with these results, our patients treated with insulin for less than one month had no significant insulin binding to $\operatorname{IgG}$, whereas those of the patients treated for two years or more in whom IgGbinding was determined, all showed significantly elevated levels, as can be seen from Table 2 .

In the normal subjects, the $24 \mathrm{hr}$ variation in IRI (Fig. 1) reflects increased postprandial pancreatic insulin secretion $[10,18]$. In the diabetics of juvenile type studied here (Figs. 2-5) there are no signs of

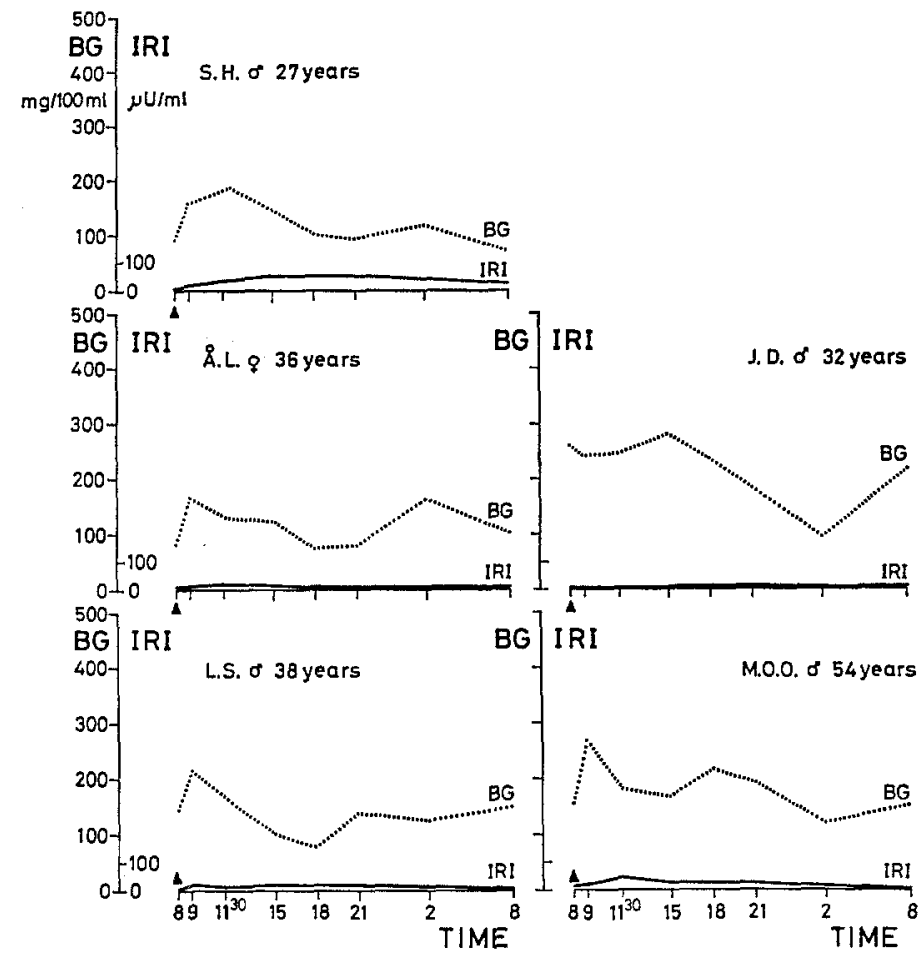

Fig. 2. Twenty-four hour variations in total IRI and BG in 5 short-term diabetics treated with a single daily insulin injection in the morning; indicated with a black triangle in the diagrams

from different diabetics. The method based upon dilution and dextran-charcoal separation [19] determines only about $60 \%$ of the total IRI due to incomplete dissociation of the insulin-antibody complexes. Therefore, we find it necessary to use a method in which the insulin is separated from the antibodies prior to the IRI-assay.

It has been shown that total IRI rises from subnormal levels before treatment to above-normal levels simultaneously with the formation of insulin antibodies during the first few months of insulin treatment [16]. The fasting total IRI varied in the range of 0 to 10,000 $\mu \mathrm{U} / \mathrm{ml}$ with a median of about $200 \mu \mathrm{U} / \mathrm{ml}$ in 155 nonresistant insulin-treated diabetic patients and showed postprandial or BG induced increases in IRI. This does not rule out the possibility that there was some residual endogenous insulin secretion of significance even though our method could not detect it. Most of the patients in Figs. $2-5$ exhibit definite increases in the total IRI after the insulin injections, with subsequent falls in IRI. This $24 \mathrm{hr}$ variation is however, relatively small in comparison to the between-patient variation. The four diabetics showing the highest levels of total IRI also show the highest increases after the morning injection. This is probably due to the increased level of antibody, which binds and retains the insulin in the circulation for a prolonged period of time.

It appears that the patients receiving the quick- 
acting Actrapid and ordinary insulin showed higher rates of increase in total IRI than those treated with the protracted-acting Lente, Rapitard and NPH-insulin only. This is in agreement with the results of absorption studies [6] and the well known differences in the timing of the hypoglycemic effect.

There is apparently no relationship between BG and IRI in the insulin treated patients shown in Figs. the BG levels in Fig. 6 it is thus likely that the longterm patients with highly elevated total IRI have less "free" IRI than the short-term patients. Differences in tissue sensitivity to insulin may, however, also play a role.

In a study of endogenous insulin secretion in response to a glucose-arginine infusion test in juvenile diabetics during the first year of insulin treatment it

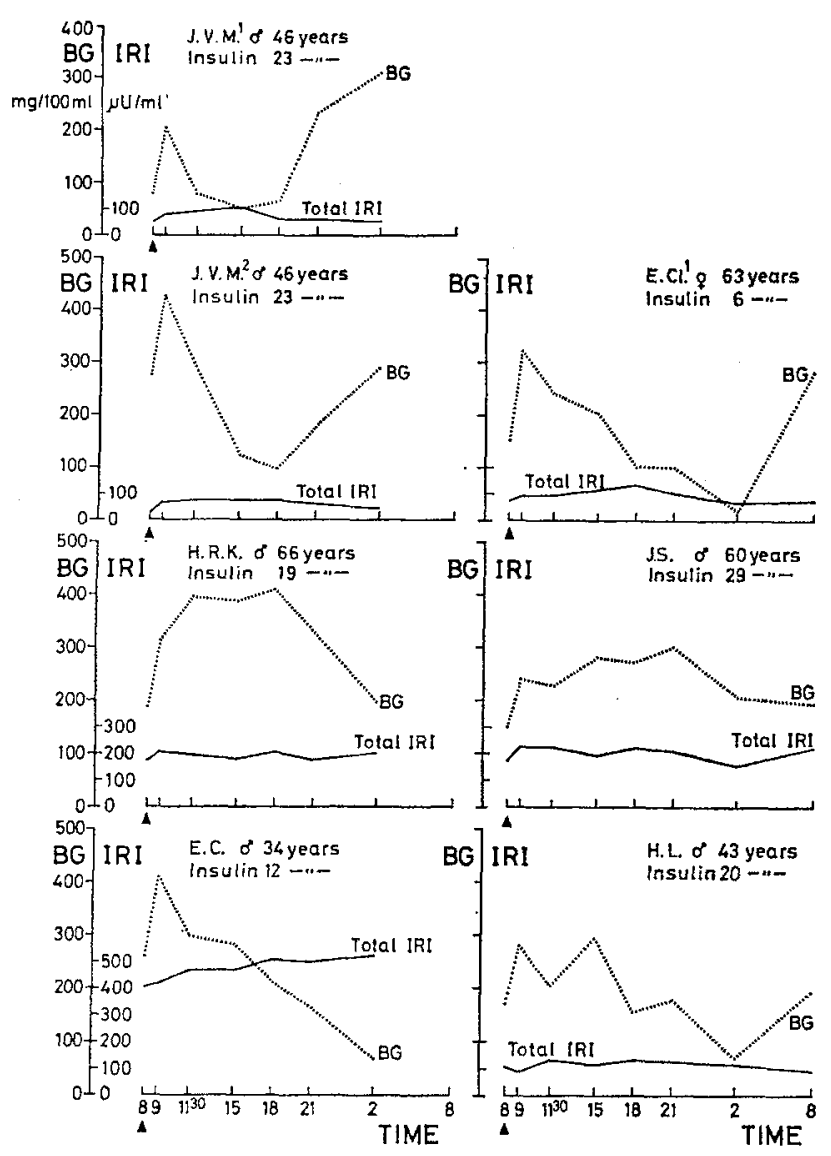

Fig. 3. Twenty-four hour variations in total IRI and BG in 6 long-term diabetics treated with a single daily insulin injection given in the morning; indicated with a black triangle in the diagrams. In one of the patients (J.V.M.), the $24 \mathrm{hr}$ variation was studied twice

$2-5$. This is not surprising, as the variation in BG is due to many factors apart from the IRI level, e.g., food intake and physical activity. The BG peak at 09.00 seen in almost all patients indicates that the rise in IRI after the morning injection is too small even in the cases receiving quick-acting insulin. The dynamic character of the binding and dissociation of insulin and antibody $[2,3,5]$ makes it difficult to define and measure the concentration of "free" biologically active insulin in patients with antibodies. Considering

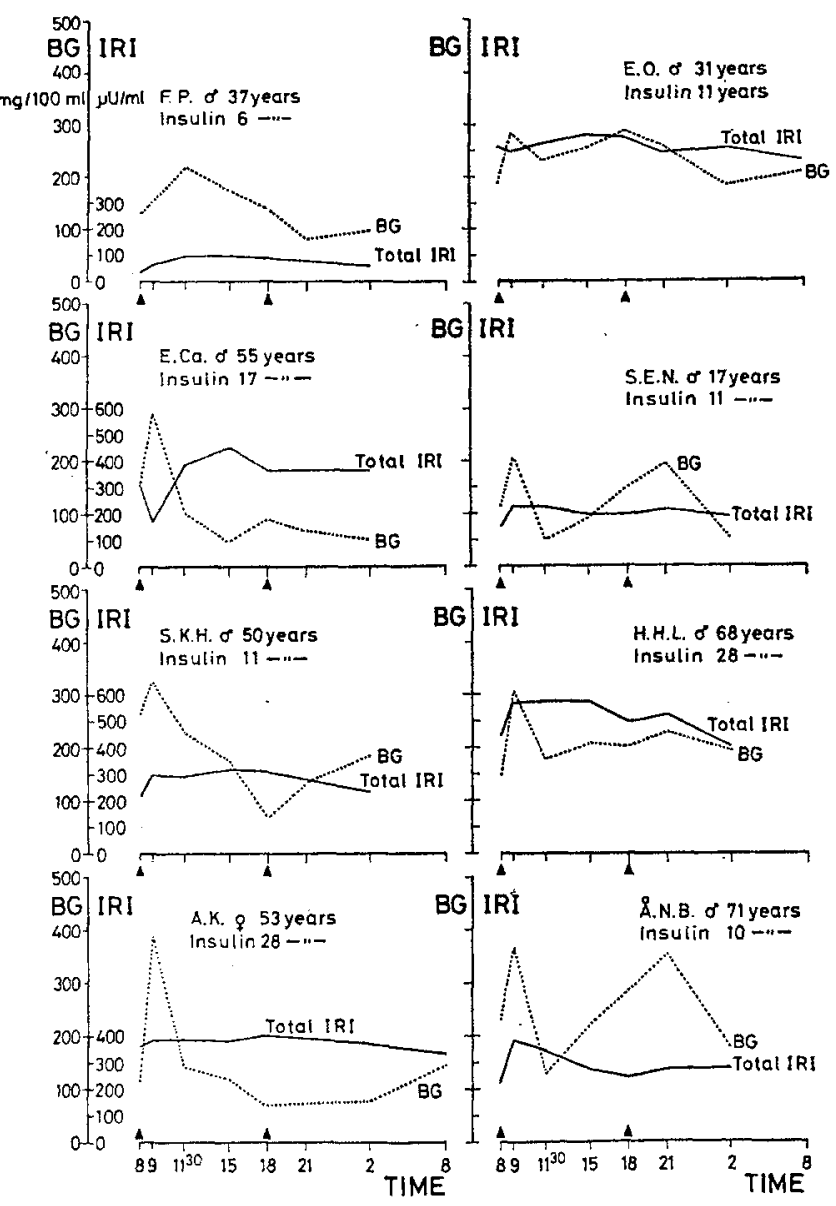

Fig. 4. Twenty-four hour variations in total IRI and BG in 8 long-term diabetics treated with two daily insulin injections given in the morning and in the evening; indicated with black triangles in the diagrams

was found that an initial remission phase, with improvements in endogenous insulin secretion and control of diabetes was followed by a gradual deterioration of control and failure of insulin secretion [20]. The superior degree of control of our short-term patients in comparison with the long-term patients (Table 2) is probably due to such a residual beta-cell secretion in the short-term patients, whereas the long-term patients have no significant endogenous insulin secretion. This is in agreement with the findings in $[7,17]$. 
The reasons for the gradual disappearance of residual beta-cell secretion are unknown. Several factors, including cellular immune reactions against exogenous insulin preparations, have been suggested [20].

The results in Table 2 seem to suggest that the inferior blood glucose control of the long-term patients
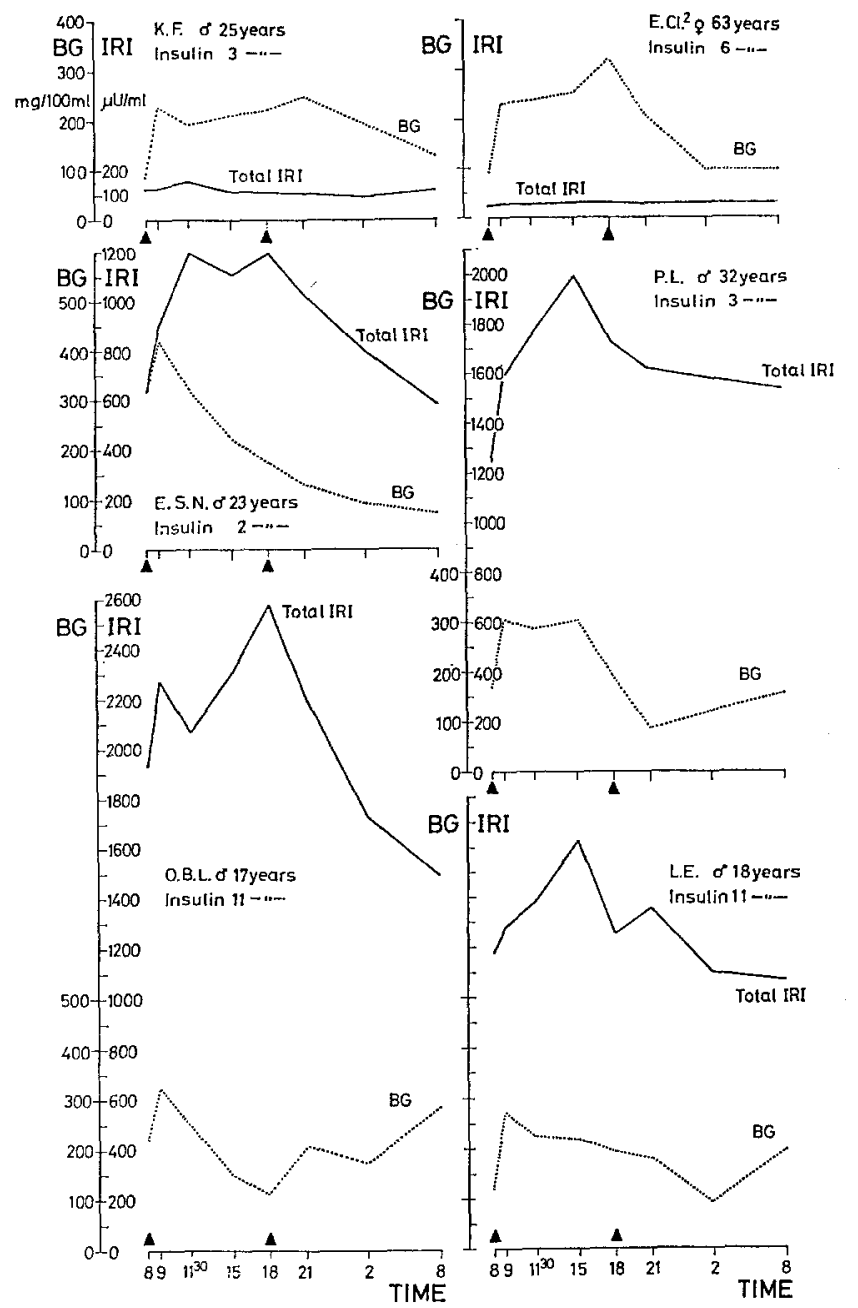

Fig. 5. Twenty-four hour variations in total IRI and BG in 6 long-term diabetics treated with two daily insulin injections given in the morning and in the evening; indicated with black triangles in the diagrams

was related to the increased level of total IRI. But the lack of a positive correlation between the mean $24 \mathrm{hr}$ level of total IRI and the M-value or the urine glucose excretion in the long-term patients speaks against it. The superior degree of blood glucose control in the short-term patients is therefore ascribed to other factors, e.g., residual endogenous insulin secretion.

It has been suggested [11] that stable diabetics had insulin antibodies with a high "buffer power", defined as the per cent change in total insulin needed to produce a $100 \%$ change in free insulin ( ${ }^{125}$ I-insulin bound to charcoal). However, the insulin-antibody complexes in diabetics dissociate with half-times of about $3-5$ min (quick dissociation and about $1^{1 / 2}$ to $7 \mathrm{hrs}[2,3$, 5]. Therefore, the immediate reaction to insulin injections may be diminished because of the binding of insulin by circulation antibodies. The subsequent slow release of insulin from the antibody complexes may provide the tissues with a continous supply of insulin for many hours and even days, and result in recurrent hypoglycemic episodes in the absence of insulin therapy $[3,4,5]$. These original dissociation studies and their relevance to hypoglycemia have later been confirmed. Thus in [27] and [23] some types of spontaneous hypoglycemia where ascribed to enhanced release of insulin from antigen-antibody complexes

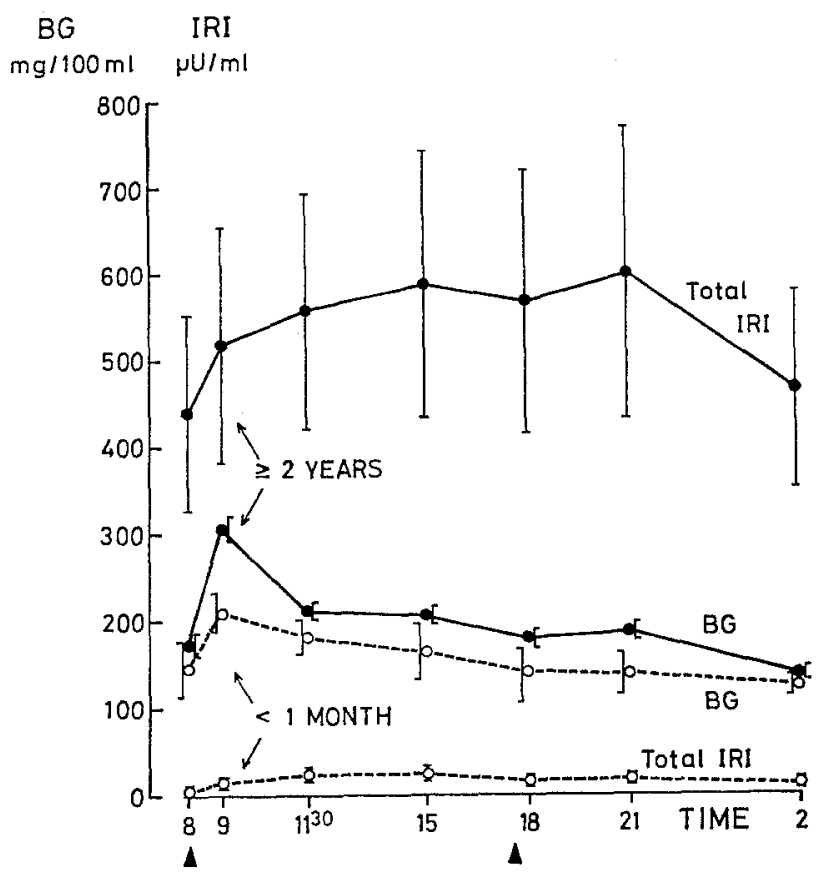

Fig. 6. Means and S.E.M. of total IRI and BG in the group of 5 short-term patients without insulin antibodies and in the group of 19 long-term patients

rather than insulin overdosage, and in [15] hypoglycemia was described in patients with insulin antibodies who did not receive exogenous insulin-treatment at the time of the investigation. An unambiguous relation between hypoglycemia and insulin antibodies has been shown in a newborn non-diabetic infant who had large amounts of insulin antibodies and antibody bound insulin in her serum at birth [26]. In this case - contrary to the many similar cases reported in adults - insulin injections can be ruled out. 
Our results showed that patients with hypoglycemic episodes (Table 2) had a significantly higher mean level of total IRI than the remaining patients, which is in agreement with the findings $[3,4,5,26]$ concerning the dissociation of the circulating "depot insulin" being independent of the metabolic needs for insulin.

Acknowledgements. The authors wish to thank Dr. Aa. H. Christiansen for the determinations of insulin binding to IgG, and Mrs. Bente Hansen and Mrs. Erna Willert for their excellent technical assistance.

\section{References}

1. Belmonte, M. M., Colle, E., DeBelle, Murthy, D. Y. N.: Variability of NPH insulin preparations. Canad. med. Ass. J. 104, 133-138 (1971)

2. Berson, S. A., Yalow, R. S., Bauman, A., Rothschild, M. A., Newerly, K.: Insulin-I131 metabolism in human subjects: Demonstration of insulin binding globulin in the circulation of insulin treated subjects. J. clin. Invest. 35, 170-190 (1956)

3. Berson, S. A., Yalow, R. S.: Studies with insulin-binding antibody. Diabetes 6, 402--407 (1957)

4. Berson, S. A., Yalow, R. S.: Isotopic tracer in the study of diabetes. In Lawrence, J. H. and Tobias, C. A., (Eds.): Advances in biological and medical physics, New York City: Academic Press Inc. Vol. 6, 349-430 (1958)

5. Berson, S. A., Yalow, R. S.: Quantitative aspects of the reaction between insulin and insulin-binding antibody. J. clin. Invest. 38, 1996-2016 (1959)

6. Binder, C.: Absorption of injected insulin. Thesis, Copenhagen (1969)

7. Block, M. B., Mako, M. E., Steiner, D. F., Rubenstein, A. H.: Circulating C-peptide immunoreactivity. Diabetes 21, 1013-1026 (1972)

8. Christiansen, Aa.H.: Radioimmunoelectrophoresis in the dermination of insulin-binding to IgG. Horm. Metab. Res. 5, 147-154 (1973)

9. Chu, P.-C., Conway, M. J., Krouse, H. A., Goodner, C. J.: The pattern of response of plasma insulin and glucose to meals and fasting during chlorpropamide therapy. Ann. intern. Med. 68, 757-769 (1968)

10. Deschamps, I., Heilbronner, J., Lestradet, H., Canivet, J.: Les variations de l'insuline chez le sujet normal au cours de nycthémere. Ann. Endocr. (Paris) 30, 589-594 (1969)

11. Dixon, K., Exon, P. D., Hughes, H. R.: Insulin antibodies in aetiology of labile diabetes. Lancet. 1972, I, 343-347

12. Galloway, J. A, Root, M. A., Rathmacher, R. P., Carmichael, R. H.: A comparison of acid regular and neutral regular insulin. Diabetes 22, 471-479 (1973)

13. Ginsberg, S., Block, M. B., Mako, M. E., Rubenstein, A. H.: Serum insulin levels following administration of exogenous insulin. Endocrinol. Metab. 36, 1175-1179 (1973)

14. Hansen, Aa. P., Johansen, K.: Diurnal patterns of blood glucose, serum free fatty acids, insulin, glucagon and growth hormone in normals and juvenile diabetics. Diabetologia 6, 27-33 (1970)

15. Harwood, R.: Insulin-binding antibodies and "spontaneous" hypoglycemia. New Engl. J. Med. 262, 978-979 (1960)
16. Heding, L. G.: Determination of total serum insulin (IRI) in insulin-treated diabetic patients. Diabetologia 8, 260266 (1972)

17. Johansen, K.: Endogenous plasma insulin in a juvenile diabetic after ten years of insulin therapy. Arch. intern. Med. 127, 139-140 (1971)

18. Malherbe, C., Gasparo, M. de, Hertogh, R. de, Hoet, J. J.: Circadian variations of blood sugar and plasma insulin levels in man. Diabetologia 5, 397-404 (1969)

19. Martin, F. I. R., Russell, J.: A simple method for determining plasma insulin in the presence of endogenous insulin antibodies. Diabetologia 10, 93-96 (1974)

20. Menzel, R., Michaelis, D., Neumann, I., Schultz, B., Wilke, W., Wulfert, R., Michael, R., Bibergeil, H.: Remission phase in newly diagnosed insulin treated juvenile diabetes: $\mathrm{Be}$ haviour of glucose, FFA, HGH and Total-IRI during combined glucose arginine infusion; Development of antibodies against exogenous insulin. Endokrinologie 62, $100-106$ (1973)

21. Metz, R., Bowers, M.: Serum insulin in insulin-treated diabetics. Diabetes 20, Suppl. 1, 368 (1971)

22. Metz, R., Bowers, M.: Plasma insulin, glucose and free fatty acid relationships in insulin-treated diabetics. Diabetes 21, Suppl. 1, 325 (1972)

23. Molnar, G. D., Taylor, W. F., Langworthy, A. L.: Plasma immunoreactive insulin patterns in insulin-treated diabetics. Mayo Clin. Proc. 47, 709-719 (1972)

24. Moxness, K. E., Molnar, G. D., Taylor, W. F., Owen, C. A., Ackerman, E, Rosevear, J. N.: Studies of diabetic instability. I. Immunoassay of human insulin in plasma containing antibodies to pork and beef insulin. Metabolism 20, 1074-1082 (1971)

25. Munkgaard Rasmussen, S., Parbst, E., Vølund, Aa.: Comparison of the Hagedorn-Jensen and the glucose oxidase method for blood glucose determination. Fifth Annual Meeting of the Scandinavian Society for the Study of Diabetes, 1969. Diabetologia 5, 429 (1969)

26. Nakagawa, S., Suda, N., Kudo, M., Kawasaki, M.: A new type of hypoglycyemia in a newborn infant. Diabetologia 9, 367-375 (1973)

27. Pal, S., Gupta, N. N., Mehrotra, R. M. L., Sircar, A. R., Chaturved, K. G.: Insulin antibodies in diabetes mellitus. Indian. J. med. Res. 57, 573-578 (1969)

28. Quickel, K. E., Feldman, J. M.: Serum-insulin levels in patients on insulin. Lancet 1971 II, 212

29. Rigas, A. N., Bittles, A. H., Hadden, D. R., Montgomery, D. A. D.: Circadian variation of glucose, insulin, and free fatty acids during long-term use of oral hypoglycemic agents in diabetes mellitus. Brit. med. J. 1968 IV, 25-28

30. Schlichtkrull, J., Munck, O., Jersild, M.: The M-value, an index of blood sugar control in diabetics. Acta med. scand. 177, 95-102 (1965)

31. Schlichtkrull, J., Brange, J., Christiansen, Aa. H., Hallund, O., Heding L. G., Jørgensen, K. H.: Clinical aspects of insulin-antigenicity. Diabetes 22, suppl. 2, 649-656 (1972)

Dr. Aa. Vølund

Novo Research Institute

Novo Allé

DK-2880 Bagsvaerd

Denmark 